\title{
Asian Catfish Clarias magur (Ham), a Wonder Fish for Health and Nutrition
}

\section{Bibha Chetia Borah*}

Principal Scientist and Officer in Charge, Fisheries Research Centre, Assam Agricultural University, Assam, India

*Corresponding Author: Bibha Chetia Borah, Principal Scientist and Officer in Charge, Fisheries Research Centre, Assam Agricultural University, Assam, India.

DOI: $10.31080 /$ ASNH.2020.04.0624
Received: January 04, 2020

Published: January 27, 2020

(C) All rights are reserved by Bibha Chetia

Borah.

\section{Abstract}

The Asian catfish or the walking catfish (Clarias magur) is one of the most commercially important indigenous food fishes of India. Recent assessment had put the species under 'endangered' category in the IUCN Red List, because of the critical decline in the wild population due to various known and unknown factors.With capacity to breathe atmospheric oxygen with special air breathing organ, the fish can be marketed alive to the delight of both sellers and consumers. The species has very high nutritional value not only as a food commodity with high protein content $(14.87 \pm 1.19 \%)$ but also known as a rich source for poly unsaturated fatty acids (PUFA) content (25.56\% of total lipid) amidst the fresh water cultivable fish species. The species is believed to have medicinal/ therapeutic value, and have very high market demand, particularly in the NE Region of India for its unique taste and nutritional value. Customary preparation of Magur with specific recipe and offered to new mothers during post natal care and to persons suffering from Pox on specific day of the course of infection is believed to help in fast recovery, provide mental and physical strength to the patient to resist secondary infection and related disorders. For iron deficiency as well as other illnesses and traumatic patient also Magur is traditionally offered for fast recovery, wound healing and strength. In addition, the fish has amazing self-healing capacity through regenerating lost tissue and regeneration of important organ like testis, which may further be studied for potential use in medical science too. Appropriate steps need to be taken for propagation and conservation of this species of nutritional, therapeutic and pharmacological importance.

Keywords: Asian Catfish; High Demand; Air Breathing; Nutritional Value; Poly Unsaturated Fatty Acid; Therapeutic Value; Regenerating Capacity

\section{Introduction}

The Asian catfish, Clarias magur (Ham), one of the commercially important indigenous food fish species of India, belonging to the order Siluriformes and family Clariidae was first described by Hamilton (1822) from Gangetic provinces. The geographic distribution of the species earlier known as Clarias magur is restricted to the Ganga and Brahmaputra river basins in Northern and North Eastern India, Nepal, Bhutan and Bangladesh [1] and has been described as a native species for India, Bangladesh and Nepal. In India, this species is naturally found in all the eight states of $\mathrm{NE}$ Region of India as well as in 11 other states viz. Bihar, Chandigarh, Darjeeling, Delhi, Haryana, Himachal Pradesh, Jharkhand, Madhya Pradesh, Uttaranchal, Uttar Pradesh and West Bengal. Naturally inhabiting the swamps, derelicts, weed infested shallow channels wetlands, paddy field etc. the species had been recognized as one of the most popular food fishes of India, Myanmar, Bangladesh, Srilanka and Malaysia (Mookerjee and Majumdar, 1950). The species grows to an average length of $30 \mathrm{~cm}$ and average weight $200 \mathrm{gm}$ in mature stage and hence can be included under the Small Indigenous freshwater Fish species group (SIFFS) of India, as per definition of Sarkar and Lakra, (2010).

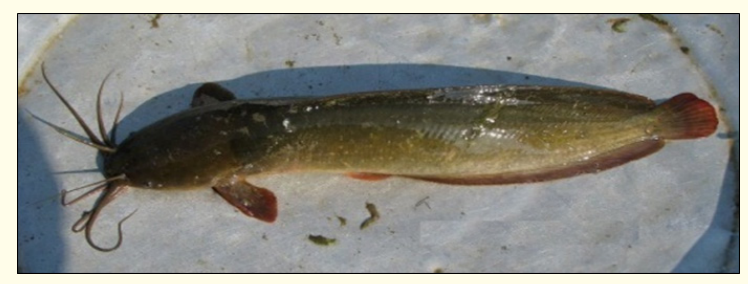

Figure 1: Asian Catfish Clarias magur (Ham).

Although the conservation status of Clarias magur was determined as 'vulnerable' by CAMP [2], on subsequent assessment the species was enlisted under threatened category in 2010 (Viswanath, 2010) while a more recent assessment had put it under 'en- 
dangered' category in the IUCN Red List (2017), because of the critical decline in the wild population due to various known and unknown factors. A good number of works have been carried out on a few biological aspects of magur like the length weight relationship [3-6], Food and feeding habit [7-10] etc. But very few works on detail assessment of the nutritional qualities of the species as well as its importance as a popular commodity with therapeutic value are available.

The present communication is an attempt to collect and review some of the works done on the fish in context to its importance as a healthy and nutritious food with therapeutic value.

\section{Importance as air breathing food fish}

Air breathing fishes are those fish species that have special capacity to survive out of water for considerable period of time by taking atmospheric oxygen for respiration with the help of extra branchial organ or some specially modified organ or part of body. The air-breathing fish have substantial advantages for aquaculture, because they can survive in harsh environment with low level of dissolved oxygen and high ammonia content and can live out of water for considerable period of time, by taking atmospheric oxygen with their special air breathing organ and modified parts of the body (Qin., et al. 1997).

The catfish Magur, also known as the 'Walking catfish' has special air breathing organs that consists of supra branchial chamber, two rosettes or air trees, four 'fans' or gill plates on each side of the branchial chamber, lined by highly vascular respiratory membrane. This ability makes this species a delight for both traders and consumers as it can be marketed alive and also makes it a highly preferred food fish among the fresh fish lovers. This quality along with its other qualities like unique taste, scale less body, less bone and high nutritional and therapeutic value makes the fish one of the very highly priced fishes of the country, fetching much higher market price in comparison to carps and other commercially important food fishes in India and Bangladesh [11,12]. The air breathing capacity enabling the species to thrive under adverse conditions like low dissolved oxygen, high stocking density and low water depth qualifies the fish as a suitable candidate for culture in small, swallow ponds [13].

\section{Importance as a source of nutrition}

Fish has been recognized as rich source of poly unsaturated fatty acids namely the $n-3$ and n-6 PUFAs, which are beneficial to human health. Fish meat and oils are good sources of unsaturated Omega -3 fatty acids, eicosapentacenoic acid (EPA, 20:5n-3) and docasahexaenoic acid (DHA, 22:6n-3) as well as its precursor alpha linolenic acid (C18:3, n-3). Compared to animal and bird meat, fish meat contains higher level of n-3 PUFAs (Calder, 2004). which are known to be highly beneficial for human health (Dhanpal., et al. 2011) as these are cardio protective, anti atherosclerotic, anti thrombotic, and anti arrythmitic and also help in reducing blood cholesterol level (Potter and Kiss,1995), regulate prostaglandin synthesis and hence induce wound healing (Bowman and Rand, 1980), and in stabilizing the electrical activity of the heart cells (Dallongeville., et al. 1991). However the PUFA composition may vary according to fish species, life stage, and environment (Marine or fresh water). Freshwater fishes are known to have lower content of PUFAs in comparison to its marine counterparts [14,15]. The fresh water fishes are known to contain higher amount of omega- 6 fatty acid (18:2 n-6) than in the marine fish [16].

Among the different freshwater cultivable fish species, Clarias magur has been identified as a good source of unsaturated fatty acid. In a study on proximate composition of four cultivable freshwater fish species conducted by Jakhar., et al. [17] revealed highest value in lipid content, mono and poly unsaturated fatty acid, EPA and Linolenic Acid in Clarias magur (Table 1). The findings revealed that magur was richest in PUFA content (25.56\%) followed by Pangas (23.37\%), Rohu (15.84\%) and Catla (12.5\%) [17]. These findings indicate superiority of the Asian catfish over these popular commercially important food fishes of India in terms of PUFA. Paul., et al. [18] also recorded 1.34 gm of Poly unsaturated fatty acid out of 5.24 gm total fat content per $100 \mathrm{gm}$ of fish muscle in Clarias magur. Out of the PUFA content Omega 3 is $0.42 \mathrm{mg}$ and Omega 6 is $0.92 \mathrm{mg}$ [18]. Presence of PUFA in considerable quantity in the muscle of Magur indicates that the species can play an important role in providing essential nutrition particularly for the ethnic population belonging to the land locked states like the NE region of India where marine fishes are not available in desired quantity and quality. Furthermore this indigenous species is one of the preferred fishes for the $95-100 \%$ fish eating population of the region and can play an important role in securing nutrition specifically for the ethnic population [19].

\begin{tabular}{|l|c|c|c|c|}
\hline \multicolumn{1}{|c|}{ Parameters (\% of total lipid) } & Catla & Rohu & Magur & Pangas \\
\hline Saturated Fatty Acid & 60.92 & 52.28 & 39.85 & 47.15 \\
\hline Mono unsaturated Fatty Acid & 15.96 & 29.55 & 31.75 & 33.47 \\
\hline Poly unsaturated Fatty Acid & 12.5 & 15.84 & 25.56 & 23.37 \\
\hline Linolenic Acid (c 18:3, n-3) & 3.04 & 2.84 & 4.72 & 2.58 \\
\hline Eicosapentaenoic Acid (C 20:5,n-3) & 1.9 & 1.29 & 2.1 & 1.93 \\
\hline
\end{tabular}

Table 1: Fatty acid composition in selected fresh water fishes [17].

\begin{tabular}{|l|c|c|c|c|}
\hline $\begin{array}{c}\text { Parameters } \\
\text { (\%) }\end{array}$ & Catla & Rohu & Magur & Pangas \\
\hline Moisture & $77.5 \pm 6.5$ & $75.46 \pm 6.0$ & $73.49 \pm 5.9$ & $74.57 \pm 6.0$ \\
\hline Protein & $10.11 \pm 0.08$ & $9.53 \pm 0.72$ & $14.87 \pm 1.19$ & $13.60 \pm 0.98$ \\
\hline Lipid & $1.2 \pm 0.08$ & $2.9 \pm 0.21$ & $7.90 \pm 0.63$ & $4.98 \pm 0.38$ \\
\hline Ash & $2.7 \pm 0.22$ & $2.20 \pm 0.17$ & $3.74 \pm 0.28$ & $1.25 \pm 0.28$ \\
\hline
\end{tabular}

Table 2: Proximate Composition (\%) of selected freshwater Fishes [17]. 
The comparative proximate analysis of these fish species (Table 2) further supported the superior nutritional value of Magur in terms of protein content, total Lipid and ash content [17]. Bogard., et al. [20] also reported $16.5 \mathrm{~g}$ protein, $1.3 \mathrm{~g}$ fat, $1.1 \mathrm{~g}$ ash content along with $326 \mathrm{k}$ calorie energy per $100 \mathrm{~g}$ of edible muscle of the species. In all these three parameters the value of Magur is the highest indicating its importance as food for human health and nutrition. In addition the presence of different Vitamins particularly the vitamins A (6.03 IU/100gm), Vitamin D (44.73 IU/100gm) and Vitamin E (0.15 IU/100gm) indicates its importance as a valuable source for these nutrients [18]. Besides vitamins presence of different human health friendly minerals (Table 3 ) and 18 beneficial amino acids in considerable quantity as component of protein (Table 4) places this fish as a wonderful food item with distinction [18]. Thorat [21] also reported that flesh, bone and other organs of the species is rich in mineral, vitamins A, B and D.

\begin{tabular}{|l|c|}
\hline Mineral & mg/100g muscle \\
\hline Calcium & 222.36 \\
\hline Phosphorus & 129.42 \\
\hline Sodium & 201.49 \\
\hline Potassium & 262.09 \\
\hline Iron & 2.20 \\
\hline Manganese & 0.21 \\
\hline Zinc & 0.68 \\
\hline Selenium & 0.43 \\
\hline
\end{tabular}

Table 3: Mineral content in Clarias magur [18].

\section{Therapeutic value of Magur}

Clarias magur is popularly known as a food with immense therapeutic value. The high nutrient content may be the reason for popular custom prevailed in NE Region of feeding magur to the new mothers during post natal care. It is believed that feeding Magur post delivery of the baby, helps in early recovery of the mother, healing of womb and other related organs of the mother's body.

\begin{tabular}{|l|c|c|c|}
\hline Parameter & $\mathbf{\%} / \mathbf{1 0 0 g}$ & Parameter & $\mathbf{\% ~ / 1 0 0 g}$ \\
\hline Protein & 16.26 & & \\
\hline Arginine & 0.72 & Aspartic acid & 1.83 \\
\hline Histidine & 0.67 & Serine & 0.87 \\
\hline Iso leucine & 0.79 & Glutamic acid & 2.39 \\
\hline Leucine & 1.36 & Proline & 0.21 \\
\hline Methionine & 0.40 & Glycine & 2.32 \\
\hline Lysine & 0.69 & Valine & 1.06 \\
\hline Phenylamine & 0.62 & Alanine & 1.18 \\
\hline Threonine & 0.82 & Cysteine & 0.02 \\
\hline Tryptophan & 0.19 & Tyrosene & 0.12 \\
\hline
\end{tabular}

Table 4: Protein and amino acids in Clarias magur \% per 100 gm muscle [18].
There is popular believe that persons suffering from serious illnesses caused by Pox virus (Chicken pox) recover and relieved faster from the blisters and scars caused by pox virus when fed with Magur. Customary preparation of Magur is generally done with fermented bamboo shoot following specific recipe (known as hukoni, meaning healing, in the state of Assam, NE India) and offered to the patient suffering from pox with traditional prayers to God (known as Aai in Assam, meaning Mother) on specific day ( $5^{\text {th }}$ or $7^{\text {th }}$ day) of the course of infection. It is believed that the pox God (Aai) become satisfied with this offering of Magur and leaves the patients's body. In fact, it has been observed that this customary offering of Magur helps in fast recovery, provides mental and physical strength to the patient to fight the post infection related disorders. Regular supplementation of Magur to people with iron deficiency syndrome leading to anaemic condition is known to have very beneficial impact, particularly on undernourished children, new mothers and young and adolescent girls. For other illnesses and traumatic patient also magur is offered for fast recovery, wound healing and strength.

\section{Regenerating capacity of Magur}

Recent reports have revealed that Magur has amazing capacity of regeneration of certain lost organs and self healing of wound and cut part of the body $[22,23]$. Regeneration is the process of renewal of lost or removed part of a living body. The process of regeneration in broad sense is the resultant of vegetative reproduction of a variety of component cells required to recreate the lost part. While all animals have the capacity to produce cells and repair wounds of body to certain extent, the capacity to regenerate lost organ or part of organ varies in different species and is restricted to some organs and in some animals. Some invertebrates have the ability to regenerate the entire organism, example, Planarians and Hydra (Wittlieb., et al. 2006, Van Wolfswinkel., et al. 2014). Some species of phylogenetically primitive vertebrates such as amphibians (Urodele amphibians, Salamanders) and fish (Zebrafish Danio rerio, a teleost species) are capable of regenerating certain organ or part of body like heart, limbs, fins, optic nerve scales, muscles and spinal cord etc. but not the entire body $[24,25]$.

The technology in vogue, for artificial breeding and seed production of Magur requires dissection of the male brooders to take out the testis for preparation of sperm solution for dry fertilization of stripped off mature eggs of female fish [26]. In this process, the male brooders do not survive and a considerable number of male magur brooders need to be sacrificed to carry out artificial breeding, resulting in tremendous impact on the male brood stock population. Further, the male fishes so sacrificed are not in marketable form (dead with cut and wound), making the technology not economically viable for the farmers (Figure 2). This inherent problem, that put a question mark on its economical and ecological viability, is one of the major reasons for less adoption and popularisation of the technology [27]. 
In an attempt made by ChetiaBorah and Gogoi [22] to keep the fish alive after dissection and removal of the testis, it was observed that the fish has the amazing capacity to heal the wound without any medication or stitching within 30-40 days. Recently Sanap., et al. [10] reported post surgery survival of the male brooders of the species, by stitching with absorbable stitching thread. The present communication includes the results of the further study on refinement of the technology by using the self healing and regenerating capacity of the fish without stitching within 30-35 days, the process of self healing was completed and the incision mark almost disappeared, (Figure 3-5). This was in agreement with the preliminary report on the amazing self healing capacity of the fish [22]. This amazing observation revealed that the fish has a remarkable capacity of self healing through regeneration of lost tissue. Further study on regeneration of removed testis revealed that after a period of 12 months of culture under controlled condition, the regeneration of testicular tissue was recorded with apparent development indicating testicular maturity [23].

This ability of certain animals to regenerate damaged or lost organ of body to different extents is a phenomenon that has puzzled scientists and has been under investigations for several decades. Natural scientists have been actively pursuing the problem of organ regeneration since the 17 th century by utilizing lower vertebrates possessing exceptional regenerative capacity (Dinsmore, 1991). Human organs are subjected to a variety of injuries, but have a limited ability to heal and regenerate its lost tissue or organ The present findings on the wonderful capacity of Magur to regenerate its surgically removed testis would open a new direction of research towards utilizing this capacity for the benefit of humanity.

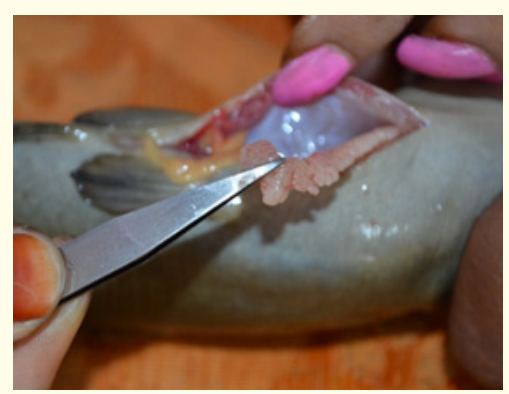

Figure 2

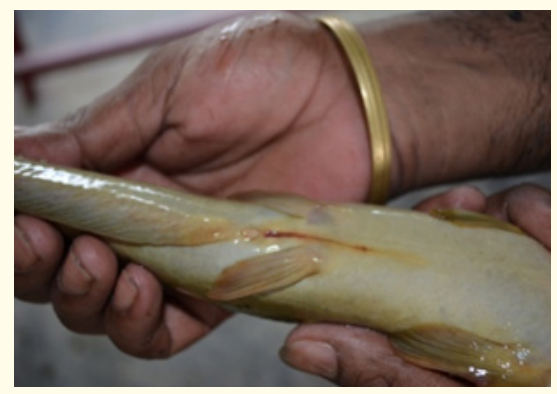

Figure 3

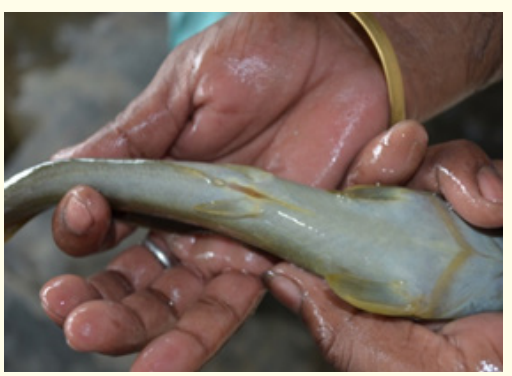

Figure 4

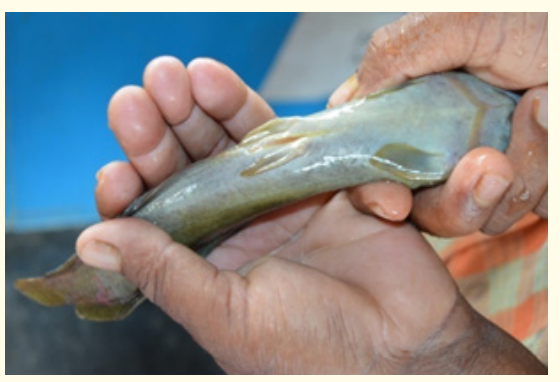

Figure 5

Figure 2-5: Dissection of male Magur (2) and the process of self healing (3-5).

\section{Conclusion}

The excellent nutritional quality including the PUFA content of this fresh water catfish Clarias magur along with its therapeutic value qualifies this fish as a highly preferable food fish species. Further its regenerating capacity can be an interesting avenue for study for utilizing the quality for the benefit of human being. The species can prove to be a potential candidate for culture and propagation under changing climatic condition too due to its special air breathing capacity and ability to thrive under adverse condition. This traditional knowledge on therapeutic value of Magur fish prevailed in North East India needs to be validated through appropriate study. Appropriate steps to be taken for propagation and conservation of this endangered fish species of commercial and biological, ecological and pharmacological importance vis a vis as one of the reliable food sources for eradication of malnutrition.

\section{Bibliography}

1. Ng HH and Kottelat M. "The identity of Clarias batrachus ( Linneaues, 1758), with the designation of a neotype (Teleostei: Clariidae)". Zoological Journal of Linnean Society 153 (2008): 725-732.

2. CAMP. Report of the workshop on "Conservation Assessment and Management plan (CAMP) for Freshwater fishes of India. Zoo Outreach Organisation and NBFGR, Lucknow 22-26 September 1997, (1998): 156.

3. Shendge AN. "Length weight Relationship in Freshwater cat fish Clarias batrachus (Linn)". Journal of Indian Fisheries Association 36 (2009): 21-24. 
4. Anirudh Kumar., et al. "Length weight relationship and Relative Condition Factor of Clarias batrachus (Linn, 1758), from Gaurmati fash farm, Kawardha, Chattishgarh, India". International Journal of Current Microbiology and Applied Sciences 6.12 (2017): 1425-1431.

5. Chowdhary S and Srivastava PP. "Length Weight Relationship (LWR) of threatened Asian Catfish, Clarias batrachus under poor availability in natural condition from Unnao, Uttar Pradesh, India". Advances in applied Science Research 4 (2013): 138-141.

6. Sahoo SK., et al. "Length weight relationship and growth performance of different life statges of hatchery produced magur (Hamilton, 1822)". Aquaculture Research 50.5 (2019).

7. Jhingran VG. "Fish and Fisheries of India". Hindustan Publishing Corporation (India), Delhi (1982): 665.

8. Ramesh I and Kiran BR. "Food and feeding habit of Catfish Clarias batrachus (Linn) in Bhadravathi area, Karnataka". International journal of Research in Environmental Science (IJRES) 2.4 (2016): 56-59.

9. Sakhare VB and Chalak AD. "Food and feeding habits of Clarias batrachus (Linn). from Ambajogai, Maharashtra, India”. Journal of Fisheries 2.2 (2014): 148-150.

10. Sanap BN., et al. "Post-dissection survival, Conservation and reutilization of Clarias batrachus (Linnaeus, 1758) male brood stock". International journal of Current Microbiology and Applied Sciences 7 (2018): 2010-2017.

11. Debnath Surajit. "Clarias batrachus, the medicinal fish: An excellent candidate for aquaculture and employment generation". International conference on Asia Agriculture and Animal IPCBEE IACSIT Press, Singapore (2011).

12. Hossain QMA., et al. "Artificial breeding and nursery practices of Clarias batrachus (Linn, 1758)". Science World 4 (2000): 3237.

13. Chetia Borah Bibha. "Potential utilization of small homestead ponds as component of family farming in Assam". In: Fishing Chimes, ISSN 0971-4529. 38 (2018): 34-41.

14. Vlieg P and Body DB. "Lipid Contents and fatty Acid Composition of some New Zealand Freshwater finfish and marine finfish, shellfish and roes". New Zealand Journal of Marine and Freshwater Research 22 (1988): 151.

15. Gruger EH., et al. "Fatty Acid Composition of oils from 21 species marine, freshwater fish and shellfish". Journal of American Oil Chemists society 41.10 (1964): 662-667.

16. Muhamad NA and Mohamad J. "Fatty Acid Composition of selected Malaysian fishes”. Sains Malaysiana 41 (2012): 81-94.

17. Jakhar JK., et al. "Fatty Acid composition of some selected Indian Fishes". African Journal of Basic and Applied Sciences 4 (2012): 155-160.
18. Paul BN., et al. Nutrition facts Clarias batrachus (magur), pamphlet published as a part of the Outreach Activity on nutrient profiling of fish, ICAR- Central Institute of Freshwater Aquaculture, Bhubaneswar (2015).

19. Chetia Borah Bibha. "Small indigenous Freshwater Fish species in Nutrition of ethnic population of North East India". Acta Scientific Nutritional Health 3.7 (2019): 158-167.

20. Bogard JR., et al. "Nutrient composition of important fish species in Bangladesh and potential contribution to recommended nutrient intakes". Journal of Food Composition and analysis 42 (2015): 120-133.

21. Thorat MM. "Biochemical contents of nutritional values of Clarias batrachus". International journal of Life Sciences 5 (2017): 481-482.

22. Chetia Borah B and Rimzhim Gogoi. "An observation on the amazing self healing capacity of catfish Magur (Clarias batrachus)". International Journal of Fisheries and Aquatic Studies 2 (2014).

23. Chetia borah Bibha., et al. "Regenerating capacity of Clarias magur (Ham)". 11th Indian Fisheries and Aquaculture Forum: Fostering Innovations in Fisheries and Aquaculture; Focus on Sustainability and safety. Organized by Asian Fisheries Society Indian Branch (AFSIB) on 21st to $24^{\text {th }}$ November, 2017 held at ICAR- Central Institute of Fisheries Technology, Kochi, India (2017): 142.

24. Poss K., et al. "Roles for In F gf signalling during Zebra fish fin regeneration”. Developmental Biology 222.2 (2000): 347-358.

25. Jazwinska Anna. "The amazing zebra fish". In International innovation (2012): 43-46.

26. Annon. "Breeding and culture of Magur". In Aquaculture technologies for farmers. Published by ICAR (2005): 23-29.

27. Johnson S and Weston J. "Temperature-sensitive mutations that cause stage-specific defects in zebrafish fin regeneration". Genetics 141 (1995): 1583-1595.

\section{Assets from publication with us}

- Prompt Acknowledgement after receiving the article

- Thorough Double blinded peer review

- Rapid Publication

- Issue of Publication Certificate

- High visibility of your Published work

Website: https://www.actascientific.com/

Submit Article: https://www.actascientific.com/submission.php Email us: editor@actascientific.com

Contact us: +919182824667 